\title{
Effects of Anion and Solvent on Properties of Alternating Ethylene/CO Copolymer Catalyzed by the Pd(II) Complex
}

\author{
O-Yong JEONG, Ki-Soo LEE, and Son-Ki IHM ${ }^{\dagger}$ \\ National Research Laboratory for Environmental Catalysis, \\ Department of Chemical Engineering, \\ Korea Advanced Institute of Science and Technology, \\ 373-1 Kusong-dong, Yusong-gu, Taejon 305-701, Korea
}

(Received July 10, 2000; Accepted October 18, 2000)

\begin{abstract}
Alternating copolymerization of ethylene and carbon monoxide was carried out using (dppp)Pd(OAc) $)_{2}$ anion complexes ( $\mathrm{dppp}=1,3$-bis(diphenylphosphino)propane) with various anions and solvents. Catalytic activity in a protic solvent (methanol) was found higher than that in an aprotic solvent (acetone). When $p$-toluenesulfonic acid ( $p$ TSOH) was used as an anion, molecular weight and melting temperature as well as the catalytic activity, increased with an appropriate combination of methanol and acetone instead of each methanol or acetone. The type of anion and solvent seemed important for catalytic activity and polymer properties. Catalytic activity decreased due to steric hindrance of alcohol in the order, methanol $>i$-butanol $>t$-butanol. Polymer properties such as molecular weight, melting temperature and crystalline structure as well as catalytic activity were significantly affected by the presence of water.

KEY WORDS Palladium Catalyst / Ethylene / Carbon Monoxide / Copolymerization /
\end{abstract}

Alternating ethylene-carbon monoxide copolymers can be obtained using catalysts based on Group VIIItransition metal compounds. There has been increasing interest in these polymers due to low cost, carbonyl functionality, and potential for further functionalization. ${ }^{1-3}$ The catalyst system typically consists of Pd(II) salts in methanol in combination with acids, mono- or bi-dentate phosphines, or bidentate nitrogen ligands and an oxidizing agent. Most research in this field has been focused on the copolymerization of carbon monoxide with ethylene or with $\alpha$-olefins such as propylene and styrene to increase catalytic activity. To achieve high catalytic activity, a more efficient catalyst system requires a suitable bidentate ligand and weakly- or non-coordinating anion to be replaced from the coordination site by an incoming nucleophile molecule. ${ }^{2,4-6}$ Little has been reported on the effects of anions and/or solvent on polymer properties. In general, hydrogen is used as a chain transfer agent to control the molecular weight in Ziegler -Natta and metallocene catalysts. In this system, molecular weight of copolymer depends on the nature of anions and solvent as well as hydrogen.

The copolymerization of ethylene and carbon monoxide was carried out in a mixture of protic and/or aprotic solvent using the (dppp) $\mathrm{Pd}(\mathrm{OAc})_{2} /$ anion complex catalyst. The effects of the anions and solvent and water addition on the properties of copolymer were investigated.

\section{EXPERIMENTAL}

\section{Materials}

Carbon monoxide (99.3\% purity) and ethylene (polymerization grade) were purified with columns of RIDOX and molecular sieve 5A. Palladium(II) acetate and 1,3bis(diphenylphosphino)propane (dppp) were purchased from Strem Chemicals. $p$-Toluenesulfonic acid ( $p$-TSOH, monohydrate, 99\%), trifluoroacetic acid, pentafluoro benzoic acid were directly used without purification. The solvents were purified according to standard methods.

\section{Preparation of Catalysts}

The catalyst (dppp) $\mathrm{Pd}(\mathrm{OAc})_{2}$ was prepared according to a general method. $1.00 \mathrm{~g}(4.46 \mathrm{mmol})$ of palladium acetate was dissolved in $100 \mathrm{~mL}$ acetone and filtered. To the filtrate, a solution of dppp (1.839 g, $4.46 \mathrm{mmol})$ in 20 $\mathrm{mL}$ acetone was slowly added over a period of $30 \mathrm{~min}$. Soon, needle-like crystal began to form, $20 \mathrm{~mL}$ ether were then slowly added and the mixture was allowed to stand for $30 \mathrm{~min}$. The pale-yellow precipitate was filtered, washed with $10 \mathrm{~mL}$ toluene and dried in vacuo to give a $(\mathrm{dppp}) \mathrm{Pd}(\mathrm{OAc})_{2}$.

\section{Copolymerization and Polymer Characterization}

The copolymerization of ethylene and $\mathrm{CO}$ was conducted in a magnetically driven stainless steel autoclave (Parr reactor) of $600 \mathrm{~mL}$. Air in the system was eliminated by purging with $\mathrm{CO}$. The catalyst (dppp) $\mathrm{Pd}(\mathrm{OAc})_{2}$ $(0.026 \mathrm{mmol}), p$-TSOH $(0.053 \mathrm{mmol})$ was dissolved in methanol $(10 \mathrm{~mL})$ and charged into the reactor containing methanol $(90 \mathrm{~mL})$ as solvent. Ethylene $(20 \mathrm{bar})$ and $\mathrm{CO}(20$ bar) were added to the reactor and the system was heated to $80^{\circ} \mathrm{C}$. After a period of $1 \mathrm{~h}$, the reaction was quenched to room temperature and the unreacted gas was vented. The product was recovered by filtration, washed several times with methanol, and dried in vacuo.

${ }^{13} \mathrm{C}$ NMR spectra of the copolymer were recorded at $120^{\circ} \mathrm{C}$ using a Bruker AMX-500 spectrometer operating at $125.6 \mathrm{MHz}$. Copolymer sample was dissolved in 1,1,1,3,3,3-hexafluoroisopropanol/benzene- $d_{6} \quad(4 / 1$ by vol.) up to a concentration of $10 \mathrm{wt} \%$ at ambient temperature in NMR tubes ( $5 \mathrm{~mm}$ o.d.). Tetramethylsilane was used as the internal standard. Melting temperature and heat of fusion of polymers were measured by differential scanning calorimetry (DSC) (Dupont analyst

${ }^{\dagger}$ To whom correspondence should be addressed (Tel: +82-42-869-3915; Fax: +82-42-869-5955; E-mail: skihm@mail.kaist.ac.kr). 


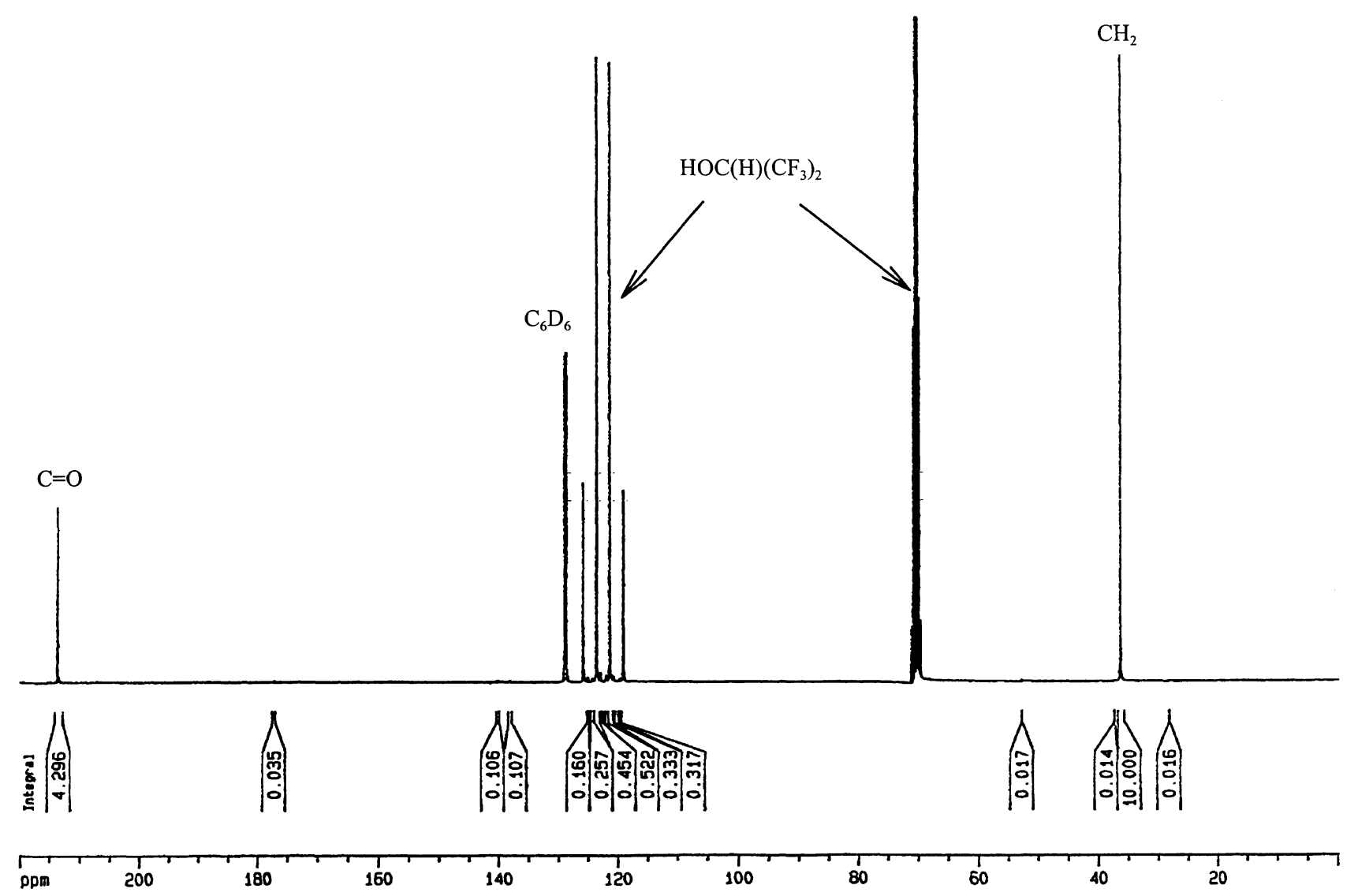

Figure 1. Typical ${ }^{13} \mathrm{C}$ NMR spectrum of ethylene/CO copolymer. Bruker AMX, 500 FT-NMR, hexafluoroisopropanol (90\%) and deuterobenzene $(10 \%)$ as solvent.

2000) at a heating rate of $10^{\circ} \mathrm{C} \min ^{-1}$. The infrared spectrum was recorded using $\mathrm{KBr}$ pellet technique with Bomem MB 102 Fourier transform infrared (FT-IR) spectrometer. X-Ray diffractomeric data were recorded using $\mathrm{Cu}-K_{\alpha}$ radiation at $30 \mathrm{keV}$ and $25^{\circ} \mathrm{C}$. Diffraction patterns of samples were taken in the range $5^{\circ}<2 \theta<60$ . Intrinsic viscosity of the copolymer was measured in $m$-cresol solution at several concentrations and $100^{\circ} \mathrm{C}$ using an Ubbelohde viscometer.

\section{RESULTS AND DISCUSSION}

\section{Characteristics of the Copolymer}

The copolymer samples were off-white powders with high melting temperature. These polyketones are insoluble in common organic solvents and dissolve appreciably only in highly polar solvents such as HFIP (hexafluoroisopropanol), $m$-cresol or in strong protic acids such as trifluoroacetic acid. Elemental analysis was in agreement with the ethylene: CO ratio of 1 . Spectroscopically (NMR and FT-IR), the polyketones obtained were identical with those previously reported. ${ }^{6}{ }^{13} \mathrm{C}$ NMR spectra (Figure 1) show two resonances due to carbonyl (217 ppm) and $\alpha$-methylene (36 ppm) carbons. The absence of resonance at $\sim 24 \mathrm{ppm}$ (observed in case of random ethylene/CO copolymers) ${ }^{7}$ indicates the absence of $\beta$-methylene carbons, leading to the conclusion that the copolymers obtained have regular structures with alternating ethylene and carbon monoxide units. The FT-IR spectrum showed a strong absorption band at $1700 \mathrm{~cm}^{-1}$ due to the $v(\mathrm{C}=\mathrm{O})$ stretch and a band at $1259 \mathrm{~cm}^{-1}$ due to the $v(\mathrm{C}=\mathrm{C})$ stretch.

\section{Effects of the Chemical Nature of Anion and Solvent}

Effective binding of the anion as well as its ability to abstract the ancillary ligand (OAc) has major control over the catalytic activity. Drent et $a .^{2}$ reported that higher electrophilicity at the palladium center with weakly- or non-coordinating anions and its corresponding higher catalytic activity with such anions must be due to easier access of substrate molecules, solvent, olefin, and $\mathrm{CO}$ to coordination sites on the metal center.

Various anions were tested for copolymerization of carbon monoxide and ethylene in a protic (methanol) and/or aprotic (acetone) solvent mixture (Table I). When $p$-TSOH was used as an anion, catalytic activity, molecular weight (intrinsic viscosity) and melting temperature increased with an appropriate combination of methanol and acetone instead of each methanol or acetone. For other anions such as $\mathrm{CF}_{3} \mathrm{CO}_{2} \mathrm{H}, \mathrm{C}_{6} \mathrm{~F}_{5} \mathrm{CO}_{2} \mathrm{H}$, and $\left(\mathrm{Ph}_{3} \mathrm{C}\right)\left[\mathrm{B}\left(\mathrm{C}_{6} \mathrm{~F}_{5}\right)_{4}\right]$ this effect was not observed. The $\left(\mathrm{Ph}_{3} \mathrm{C}\right)\left[\mathrm{B}\left(\mathrm{C}_{6} \mathrm{~F}_{5}\right)_{4}\right]$ compound as bulky anion source gave relatively higher molecular weight than other anions presumably because this compound cannot donate protons.

The catalytic activity of copolymerization in a protic solvent (methanol) was higher than in an aprotic solvent (acetone). A protic solvent serves as coinitiator as well as chain transfer agent in its reaction with the palladium complex, which forms not only a palladium methoxy spe- 
Table I. Copolymerization of ethylene with CO over ( $\mathrm{dppp}) \mathrm{Pd}(\mathrm{OAc})_{2}$ catalyst using different anions and solvents

\begin{tabular}{|c|c|c|c|c|c|c|}
\hline \multirow{2}{*}{ Anion type } & \multicolumn{2}{|c|}{ Solvent $/ \mathrm{mL}$} & \multirow{2}{*}{$\begin{array}{c}\text { Yield } \\
\mathrm{g}\end{array}$} & \multirow{2}{*}{$\begin{array}{c}\text { Activity } \\
\text { g-PK/g-Pd } \cdot h\end{array}$} & \multirow{2}{*}{$\frac{\eta^{\mathrm{a}}}{\mathrm{dL} \mathrm{g}^{-1}}$} & \multirow{2}{*}{$\begin{array}{l}T_{\mathrm{m}} \\
{ }^{\circ} \mathrm{C} \\
\end{array}$} \\
\hline & $\mathrm{MeOH}$ & Acetone & & & & \\
\hline$P$-TSOH & 100 & - & 3.8 & 1354 & 0.24 & 217 \\
\hline$P$-TSOH & 65 & 35 & 5.0 & 1771 & 0.38 & 229 \\
\hline$P$-TSOH & 35 & 65 & 6.7 & 2382 & 0.51 & 237 \\
\hline$P$-TSOH & - & 100 & 1.6 & 582 & 0.32 & 224 \\
\hline $\mathrm{CF}_{3} \mathrm{CO}_{2} \mathrm{H}$ & 100 & - & 7.1 & 2534 & 0.99 & 245 \\
\hline $\mathrm{CF}_{3} \mathrm{CO}_{2}^{2} \mathrm{H}$ & 65 & 35 & 6.9 & 2446 & 1.06 & 245 \\
\hline $\mathrm{CF}_{3} \mathrm{CO}_{2} \mathrm{H}$ & 35 & 65 & 6.0 & 2154 & 0.98 & 242 \\
\hline $\mathrm{CF}_{3} \mathrm{CO}_{2} \mathrm{H}$ & - & 100 & 2.1 & 736 & 1.04 & 249 \\
\hline $\mathrm{C}_{6} \mathrm{~F}_{5} \mathrm{CO}_{2} \mathrm{H}$ & 100 & - & 2.1 & 761 & 0.32 & 229 \\
\hline $\mathrm{C}_{6} \mathrm{~F}_{5} \mathrm{CO}_{2} \mathrm{H}$ & 65 & 35 & 0.7 & 232 & 0.02 & 231 \\
\hline $\mathrm{C}_{6} \mathrm{~F}_{5} \mathrm{CO}_{2} \mathrm{H}$ & 35 & 65 & 0.6 & 225 & 0.01 & 217 \\
\hline $\mathrm{C}_{6} \mathrm{~F}_{5} \mathrm{CO}_{2} \mathrm{H}$ & - & 100 & n.d. & - & - & - \\
\hline$\left(\mathrm{Ph}_{3} \mathrm{C}\right)\left[\mathrm{B}\left(\mathrm{C}_{6} \mathrm{~F}_{5}\right)_{4}\right]$ & 100 & - & 5.9 & 2121 & 1.06 & 237 \\
\hline$\left(\mathrm{Ph}_{3} \mathrm{C}\right)\left[\mathrm{B}\left(\mathrm{C}_{6} \mathrm{~F}_{5}\right)_{4}\right]$ & 65 & 35 & 4.6 & 1646 & 1.08 & 225 \\
\hline$\left(\mathrm{Ph}_{3} \mathrm{C}\right)\left[\mathrm{B}\left(\mathrm{C}_{6} \mathrm{~F}_{5}\right)_{4}\right]$ & 35 & 65 & 4.1 & 1479 & 1.09 & 240 \\
\hline$\left(\mathrm{Ph}_{3} \mathrm{C}\right)\left[\mathrm{B}\left(\mathrm{C}_{6} \mathrm{~F}_{5}\right)_{4}\right]$ & - & 100 & 5.1 & 1821 & 1.13 & 221 \\
\hline
\end{tabular}

Experimental conditions: (dppp)Pd(OAc) $(0.026 \mathrm{mmol})$, anion $(0.053 \mathrm{mmol}), \mathrm{P}_{\mathrm{C} 2 \mathrm{H} / \mathrm{CO}}(20 / 20 \mathrm{bar})$, solvent $(100 \mathrm{~mL}), 80^{\circ} \mathrm{C}, 1 \mathrm{~h}$. $p$-TSOH $=\mathrm{CH}_{3} \mathrm{C}_{6} \mathrm{H}_{4} \mathrm{SO}_{3} \mathrm{H} \cdot \mathrm{H}_{2} \mathrm{O}$. ${ }^{\text {a }}$ Intrinsic viscosity in $m$-cresol at $100^{\circ} \mathrm{C}$ using Ubbelohde viscometer.

Table II. Copolymerization of ethylene with $\mathrm{CO}$ over (dppp) $\mathrm{Pd}(\mathrm{OAc})_{2}$ catalyst using different alcohols

\begin{tabular}{|c|c|c|c|c|c|}
\hline \multicolumn{2}{|c|}{ Solvent mixture/mL } & $\begin{array}{c}\text { Yield } \\
\mathrm{g} \\
\end{array}$ & $\frac{\text { Activity }}{\mathrm{g}-\mathrm{PK} / \mathrm{g}-\mathrm{Pd} \cdot \mathrm{h}}$ & $\frac{\eta^{\mathrm{a}}}{\mathrm{dL} \mathrm{g}^{-1}}$ & $\frac{T_{\mathrm{m}}}{{ }^{\circ} \mathrm{C}}$ \\
\hline $\mathrm{MeOH}(100)$ & - & 3.8 & 1354 & 0.24 & 217 \\
\hline $\mathrm{MeOH}(65)$ & Acetone (35) & 5.0 & 1771 & 0.38 & 229 \\
\hline $\mathrm{MeOH}(35)$ & Acetone (65) & 6.7 & 2382 & 0.51 & 237 \\
\hline - & Acetone (100) & 1.6 & 582 & 0.32 & 224 \\
\hline$i-\mathrm{BuOH}(100)$ & - & 3.2 & 1136 & 0.44 & 201 \\
\hline$i-\mathrm{BuOH}(65)$ & Acetone (35) & 2.1 & 736 & 0.41 & 211 \\
\hline$i-\mathrm{BuOH}(35)$ & Acetone (65) & 2.9 & 1021 & 0.38 & 214 \\
\hline- & Acetone (100) & 1.6 & 582 & 0.32 & 224 \\
\hline$t-\mathrm{BuOH}(100)$ & - & n.d. & - & - & - \\
\hline$t-\mathrm{BuOH}(65)$ & Acetone (35) & 1.2 & 421 & 1.36 & 222 \\
\hline$t-\mathrm{BuOH}(35)$ & Acetone (65) & 1.9 & 686 & 0.98 & 233 \\
\hline- & Acetone (100) & 1.6 & 582 & 0.32 & 224 \\
\hline
\end{tabular}

Experimental conditions: (dppp) $\mathrm{Pd}(\mathrm{OAc})_{2}(0.026 \mathrm{mmol}), p-\mathrm{TSOH}(0.053 \mathrm{mmol}), \mathrm{P}_{\mathrm{C} 2 \mathrm{H} 4 / \mathrm{CO}}(20 / 20 \mathrm{bar})$, solvent $(100 \mathrm{~mL}), 80^{\circ} \mathrm{C}, 1 \mathrm{~h}$.

${ }^{a}$ Intrinsic viscosity in $m$-cresol at $100^{\circ} \mathrm{C}$ using Ubbelohde viscometer.

cies $\left[\mathrm{Pd}-\mathrm{OCH}_{3}\right]$ but also a palladium hydride species $[\mathrm{Pd}$ $-\mathrm{H}]$. For reactions in aprotic solvents, the initiation is possible only through a palladium hydride species $[\mathrm{Pd}-$ $\mathrm{H}$ ] by dihydrogen, which is provided by trace water (protic impurities) or trace $\mathrm{H}_{2}$ in the reactant gas. ${ }^{8-10}$

The choice of polymerization solvent affected polymer properties, especially molecular weight. Molecular weight of copolymer was lower in methanol than in acetone with various anions. Propagation reaction progressed by the addition of ethylene to $\mathrm{Pd}$-acyl and of $\mathrm{CO}$ to Pd-alkyl species alternatively. All chains were terminated mainly by reaction of methanol with various propagating species producing a new initiating species. Alcoholysis occurs from the Pd-acyl species (eq 1) and in the case of Pd-alkyl species alcoholysis (eq 2) and protonolysis (eq 3 ) were possible. ${ }^{2,11,12}$

Chain-transfer:

$$
\begin{aligned}
\mathrm{Pd}^{+1}-\mathrm{C}(\mathrm{O})-\mathrm{P} & +\mathrm{CH}_{3} \mathrm{OH} \longrightarrow \mathrm{Pd}^{+1}-\mathrm{H}+\mathrm{CH}_{3} \mathrm{OC}(\mathrm{O})-\mathrm{P} \\
\mathrm{Pd}^{+1}-\mathrm{CH}_{2} \mathrm{CH}_{2} \mathrm{C}(\mathrm{O})-\mathrm{P}+\mathrm{CH}_{3} \mathrm{OH} & \\
\longrightarrow & \mathrm{Pd}^{+1}-\mathrm{H}+\mathrm{CH}_{3} \mathrm{O} \mathrm{CH}_{2} \mathrm{CH}_{2} \mathrm{C}(\mathrm{O})-\mathrm{P} \\
\longrightarrow & \mathrm{Pd}^{+1}-\mathrm{OCH}_{3}+\mathrm{CH}_{3} \mathrm{CH}_{2} \mathrm{C}(\mathrm{O})-\mathrm{P}
\end{aligned}
$$

\section{Effects of Alcohol}

Catalytic activity increased with the addition of alcohols. The increase was significantly influenced by steric hindrance of alcohol in the order, methanol $(\mathrm{MeOH})>i$ butanol $(i-\mathrm{BuOH})>t$-butanol $(t-\mathrm{BuOH})$ as shown in Table II. Copolymerization yield was significantly lower in a $t-\mathrm{BuOH} /$ acetone mixture compared to a $\mathrm{MeOH} /$ acetone mixture. The low activity in the case of $t$ - $\mathrm{BuOH}$ may be due to other reasons. The formation of $\mathrm{Pd}-\mathrm{O}-t-\mathrm{Bu}$ is slow, the insertion of ethylene or carbon monoxide into $\mathrm{Pd}-\mathrm{O}-t-\mathrm{Bu}$ bond is slower than that into $\mathrm{Pd}-\mathrm{OCH}_{3}$ bond and $\mathrm{Pd}-\mathrm{H}$ cannot form from $\mathrm{Pd}-\mathrm{O}-t-\mathrm{Bu}^{4}$ The molecular weight and melting temperature of copolymer can be varied with a proper combination of alcohol and acetone. Especially, $t$-BuOH showed higher molecular weight than others, probably due to the absence of $\beta$-hydrogen in $t$ - $\mathrm{BuOH}$ species.

Effects of Water Addition on the Properties of Copolymer

Catalytic activity was significantly influenced by the presence of water. The promoting effect of a small amount of water on the copolymer yield was reported by Toniolo et al., ${ }^{13}$ but the effect on polymer properties was 
Table III. Copolymerization of ethylene with $\mathrm{CO}$ over (dppp) $\mathrm{Pd}(\mathrm{OAc})_{2}$ catalyst with water addition

\begin{tabular}{|c|c|c|c|c|c|c|c|c|}
\hline Solvent & $\mathrm{H}_{2} \mathrm{O}$ & $\mathrm{H}_{2} \mathrm{O}$ /solvent & Yield & Activity & $\eta^{\mathrm{a}}$ & $T_{\mathrm{m}}$ & $\Delta H_{\mathrm{f}}$ & $X_{c}{ }^{b}$ \\
\hline $\mathrm{mL}$ & $\mathrm{mL}$ & $\% \mathrm{v} / \mathrm{v}$ & $\mathrm{g}$ & g-PK/g-Pd·h & $\mathrm{dL} \mathrm{g}^{-1}$ & ${ }^{\circ} \mathrm{C}$ & $\mathrm{Jg}^{-1}$ & $\%$ \\
\hline $\mathrm{MeOH}(100)$ & - & - & 3.8 & 1354 & 0.24 & 217 & 61 & 27 \\
\hline $\mathrm{MeOH}(100)$ & 1 & 1.0 & 4.1 & 1461 & 0.29 & 219 & 60 & 26 \\
\hline $\mathrm{MeOH}(100)$ & 3 & 2.9 & 5.1 & 1807 & 0.32 & 226 & 87 & 38 \\
\hline $\mathrm{MeOH}(100)$ & 5 & 4.8 & 7.3 & 2607 & 0.43 & 238 & 114 & 50 \\
\hline $\mathrm{MeOH}(100)$ & 7 & 6.5 & 6.2 & 2225 & 0.30 & 230 & 137 & 60 \\
\hline $\mathrm{MeOH}(100)$ & 12 & 10.7 & 5.4 & 1921 & 0.10 & 228 & 90 & 40 \\
\hline THF (100) & - & - & 1.6 & 582 & 0.35 & 226 & 64 & 28 \\
\hline THF (100) & 1 & 1.0 & 2.3 & 836 & 0.36 & 226 & 73 & 32 \\
\hline THF (100) & 3 & 2.9 & 2.4 & 839 & 0.37 & 234 & 77 & 34 \\
\hline THF (100) & 5 & 4.8 & 2.7 & 975 & 0.51 & 243 & 103 & 45 \\
\hline THF (100) & 7 & 6.5 & 1.7 & 621 & 0.31 & 242 & 127 & 56 \\
\hline THF (100) & 12 & 10.7 & 1.0 & 357 & 0.13 & 233 & 79 & 35 \\
\hline
\end{tabular}

Experimental conditions: (dppp)Pd(OAc) $)_{2}(0.026 \mathrm{mmol}), p$-TSOH $(0.053 \mathrm{mmol}), \mathrm{P}_{\mathrm{C} 2 \mathrm{H} 4 / \mathrm{CO}}(20 / 20 \mathrm{bar})$, Solvent $(100 \mathrm{~mL}), 80^{\circ} \mathrm{C}, 1 \mathrm{~h} .{ }^{\mathrm{a}} \mathrm{Intrin}-$ sic viscosity in $m$-cresol at $100^{\circ} \mathrm{C}$ using Ubbelohde viscometer. ${ }^{\mathrm{b}}$ Crystallinity $=\Delta H_{\mathrm{f}} / \Delta H_{\mathrm{m}}{ }^{\circ}\left(\Delta H_{\mathrm{m}}{ }^{\circ}=227 \mathrm{~J} \mathrm{~g}^{-1}\right)$.

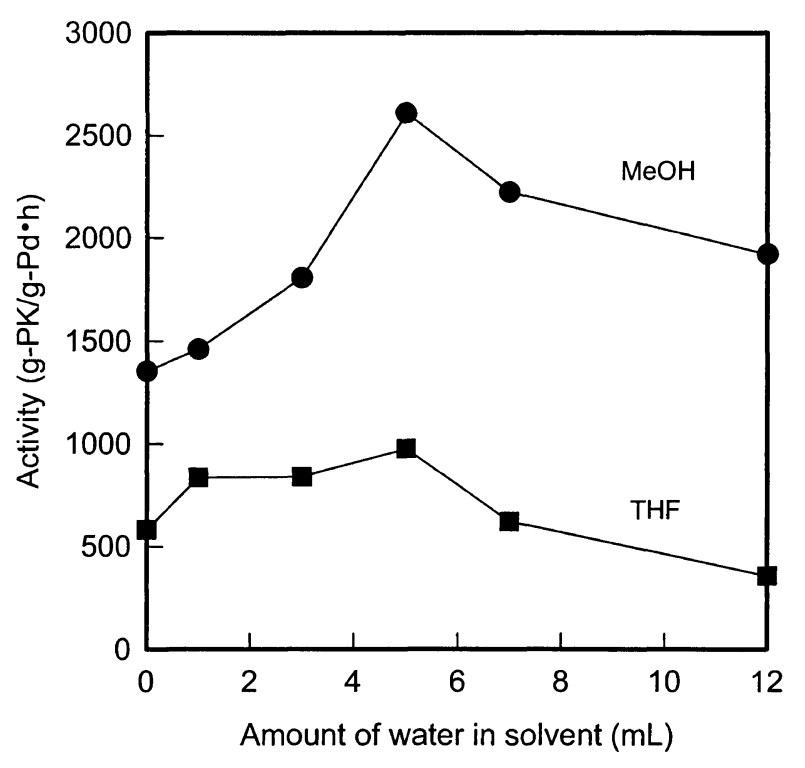

(a)

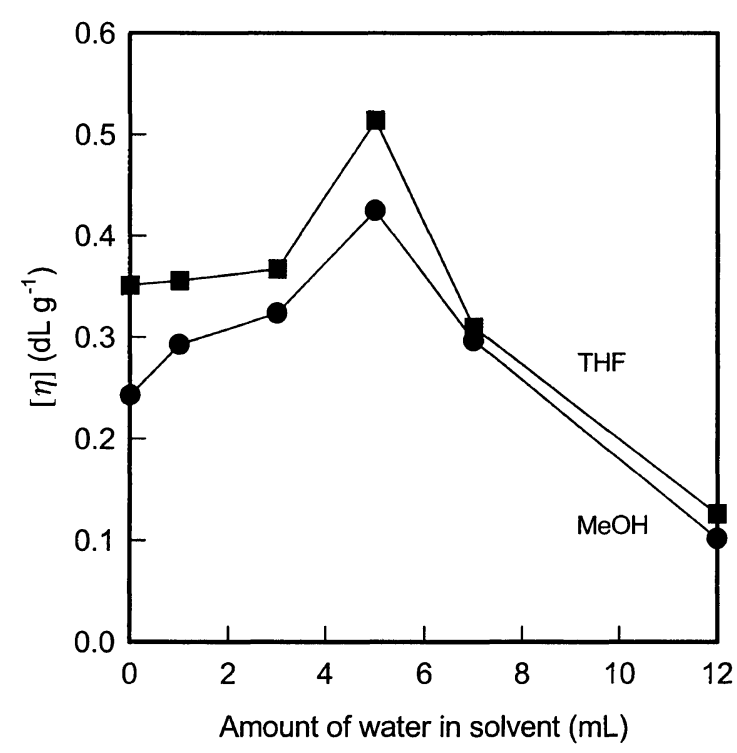

(b)

Figure 2. Effect of water addition on the activity (a) and molecular weight (b) of ethylene/CO copolymerization. Experimental conditions: (dppp) $\mathrm{Pd}(\mathrm{OAc})_{2}(0.026 \mathrm{mmol}), p-\mathrm{TSOH}(0.053 \mathrm{mmol}), \mathrm{P}_{\mathrm{C} 2 \mathrm{H} 4 / \mathrm{CO}}(20 / 20 \mathrm{bar})$, Solvent $(100 \mathrm{~mL}), 80^{\circ} \mathrm{C}, 1 \mathrm{~h}$.

not investigated in ethylene/CO copolymerization. Rieger et al. ${ }^{14,15}$ reported the effect of activator (methanol, water) on the copolymerization of propylene and $\mathrm{CO}$ over $\left[(\mathrm{dppp}) \mathrm{Pd}(\mathrm{NCMe})_{2}\right]\left[\mathrm{BF}_{4}\right]$ in methylene chloride. Molecular weight, regioregularity and elastic properties of copolymer were influenced by activator content. Table III and Figure 2 shows the results of water addition on the copolymerization of ethylene and carbon monoxide. Catalytic activity increased from 1354 up to $2607 \mathrm{~g}$ polyketone/g-Pd $\cdot \mathrm{h}$ and from 582 up to $975 \mathrm{~g}$-polyketone/ $\mathrm{g}-\mathrm{Pd} \cdot \mathrm{h}$ in the presence of $4.8 \mathrm{vol} \%$ of water in methanol and tetrahydrofuran (THF). Further addition of water decreased catalytic activity. This suggests that water competes with monomers for coordination sites of palladium metal. Catalytic activity for the copolymerization of carbon monoxide and ethylene increased since water increases the concentration of hydride species, which initiate the insertion of the olefin into a $\mathrm{Pd}-\mathrm{H}$ bond resulting in the water gas shift reaction (WGSR) as follows (eq
4). The palladium complex is well known to catalyze WGSR. $^{2}$

$$
\begin{aligned}
\mathrm{Pd}^{+2}+\mathrm{CO} & \longrightarrow[\mathrm{Pd}-\mathrm{CO}]^{+2} \\
& \stackrel{+\mathrm{H}_{2} \mathrm{O}}{\longrightarrow}[\mathrm{Pd}-(\mathrm{COOH})]^{+}-\mathrm{H}^{+} \\
& \stackrel{-\mathrm{CO}_{2}}{\longrightarrow}[\mathrm{Pd}-\mathrm{H}]^{+} \stackrel{+\mathrm{H}^{+}}{\longrightarrow} \mathrm{Pd}^{+2}+\mathrm{H}_{2}
\end{aligned}
$$

While water and methanol may be involved in the reduction of $\mathrm{Pd}^{+2}$, they can also be a source of hydrides. Figure $2 \mathrm{~b}$ shows that molecular weight is also strongly influenced by the presence of water in methanol and THF, respectively. Intrinsic viscosity increased from 0.24 up to $0.43 \mathrm{dL} \mathrm{g}^{-1}$ and from 0.35 up to $0.51 \mathrm{dL} \mathrm{g}^{-1}$ in the presence of $4.8 \mathrm{vol} \%$ of water in methanol and THF, respectively. Intrinsic viscosity shows similar variation with water to activity. The addition of water as a proton source may increase not only the concentration of active 


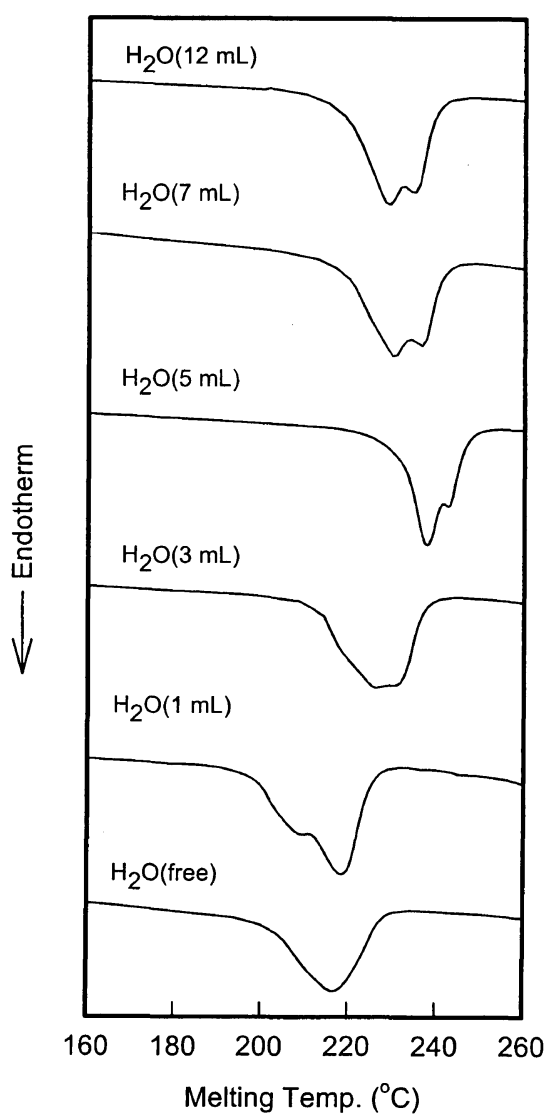

(a)

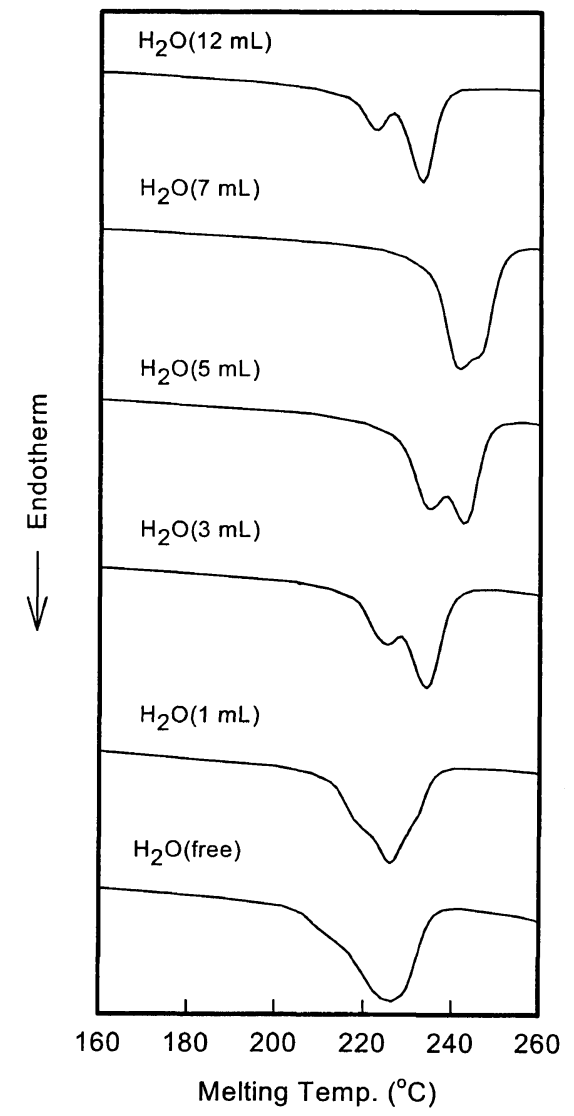

(b)

Figure 3. DSC curves of ethylene/CO copolymer with water addition in (a) $\mathrm{MeOH}$, (b) THF. Experimental conditions: (dppp)Pd(OAc) $(0.026 \mathrm{mmol}), p$-TSOH $(0.053 \mathrm{mmol}), \mathrm{P}_{\mathrm{C} 2 \mathrm{H} / \mathrm{CO}}(20 / 20 \mathrm{bar})$, Solvent $(100 \mathrm{~mL}), 80^{\circ} \mathrm{C}, 1 \mathrm{~h}$.

species, i.e., palladium hydride species, but also stability of the palladium hydride species. Increase in the stability of active species must enhance the possibility of coordination and insertion of monomers, which may increase molecular weight (or intrinsic viscosity). Excess water would accelerate chain transfer. Accordingly, intrinsic viscosity would show a maximum point with an optimum amount of water.

Figure 3 shows the DSC spectrum of ethylene/CO copolymers. The melting temperature $\left(T_{\mathrm{m}}\right)$ and crystallinity $\left(X_{c}\right)$ of copolymers were strongly influenced by the addition of water in the copolymerization and showed similar trend with molecular weight. Melting temperature and heat of fusion of copolymer increased with the addition of water as shown in Table III. Copolymers with no addition of water had one $T_{\mathrm{m}}$, but copolymers with water showed two $T_{\mathrm{m}}$. Multiple melting points are possibly due to two active sites or two different polymer phase formation. ${ }^{16}$ In the X-Ray diffractogram (XRD) (Figure 4), the copolymer was confirmed to be partially crystalline. From Table III and Figure 4, the degree of crystallinity of copolymer increased with volume ratio of water to methanol and THF up to $6.5 \mathrm{vol} \%$, then decreased beyond this ratio. Even if there is the possibility that the content of water in the solvent, used for re-deposit of isolated copolymer, may vary crystallinity, the effect of water on crystallinity of the copolymer is yet to be understood. There are two crystalline forms ( $\alpha$ and $\beta$ ) in the alternating ethylene/CO copolymers. ${ }^{17}$ The $\alpha$-phase has carbonyl groups in adjacent chains at equal heights, but the $\beta$-phase has carbonyl groups of chains at the corners of the cell pointing in different directions from those of the chain in the center of the cell. While the polymer chains are the same in each phase, orientation of the carbonyls along the chain is less ordered in the $\beta$ phase. ${ }^{18}$ The crystalline form, favored strongly, depends on polymer composition as well as other factors like temperature, and applied stress. The $\alpha$-phase has been reported in well-oriented perfectly alternating ethylene/ carbon monoxide copolymers. The $\beta$-phase is exclusive in ethylene/propylene/carbon monoxide terpolymers above $2.5 \mathrm{~mol} \%$ of propylene. ${ }^{17}$ In this study, we used two peaks at an angle of $31^{\circ}$ and $29^{\circ}$, which assigned to the $\alpha$-and $\beta$-phases (210), respectively. The $\beta$-phase decreased with content of water in copolymerization and then disappeared above 10.7 vol\% water, but the $\alpha$ phase did not disappear. This indicates that the crystalline structures of ethylene/carbon monoxide copolymers can be changed with the addition of water in copolymerization.

\section{CONCLUSIONS}

The catalytic activity of ethylene-carbon monoxide copolymerization using ( $\mathrm{dppp}) \mathrm{Pd}(\mathrm{OAc})_{2}$ /anion complexes in a protic solvent (methanol) was found higher than in 


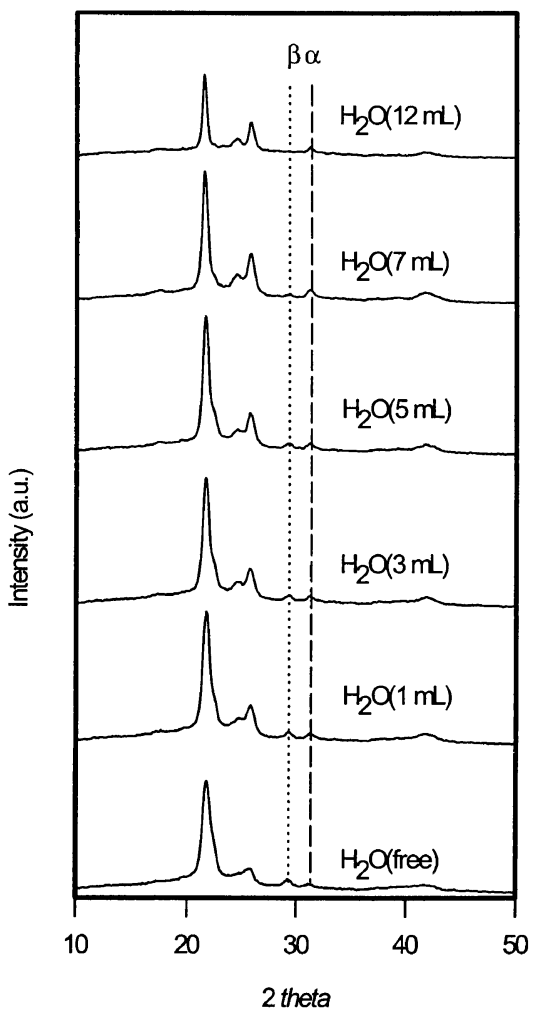

(a)

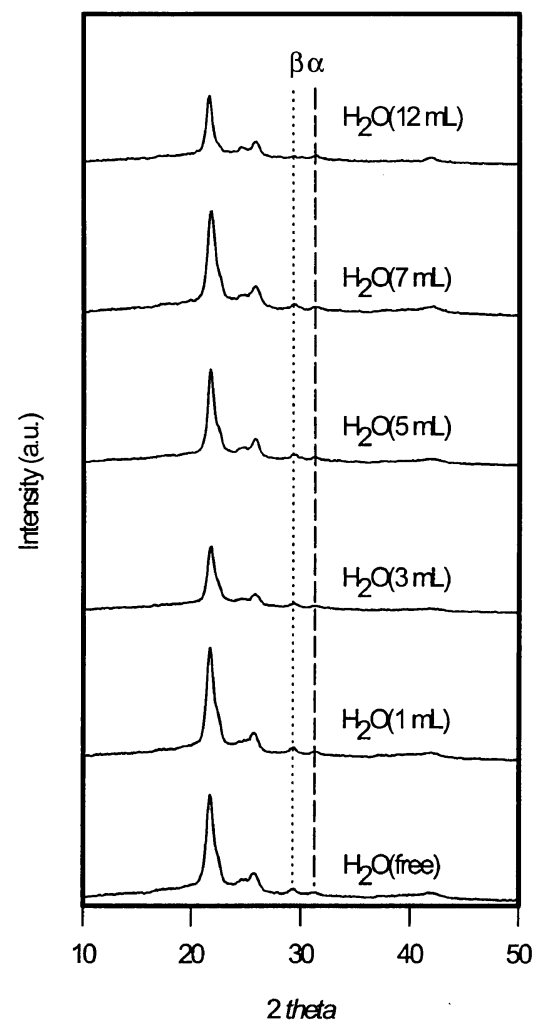

(b)

Figure 4. XRD curves of ethylene/CO copolymer with water addition in (a) $\mathrm{MeOH}$, (b) THF. Experimental conditions: (dppp) Pd(OAc) $(0.026 \mathrm{mmol}), p$-TSOH $(0.053 \mathrm{mmol}), \mathrm{P}_{\mathrm{C} 2 \mathrm{H} 4 / \mathrm{CO}}(20 / 20 \mathrm{bar})$, Solvent $(100 \mathrm{~mL}), 80^{\circ} \mathrm{C}, 1 \mathrm{~h}$.

an aprotic solvent (acetone). When $p-\mathrm{TSOH}$ was used as an anion, molecular weight and melting temperature as well as the catalytic activity could be controlled with an appropriate combination of methanol and acetone instead of each methanol or acetone. Catalytic activity decreased due to steric hindrance of alcohol in the order, $\mathrm{MeOH}>i$-BuOH $>t-\mathrm{BuOH}$. Polymer properties such as molecular weight, melting temperature and crystalline structure were affected by the presence of water. Catalytic activity increased with water possibly because increased concentration of hydride species may easily initiate the insertion of the olefin into a $\mathrm{Pd}-\mathrm{H}$ bond via water gas shift reaction.

Acknowledgments. This work was partially supported by the Brain Korea 21 Project and also by the National Research Laboratory Project of Korea.

\section{REFERENCES}

1. A. Sen, Adv. Polym. Sci., 73/74, 125 (1986).

2. E. Drent, J. A. M. Broekhoven, and M. J. Doyle, J. Organomet. Chem., 417, 235 (1991).

3. Z. Jiang and A. Sen, J. Am. Chem. Soc., 117, 4455 (1995).
4. A. X. Zhao and J. C. W. Chien, J. Polym. Sci., Part A: Polym. Chem., 30, 2375 (1992).

5. A. Sen and Z. Jiang, Macromolecules, 26, 911 (1993).

6. Z. Jiang, S. E. Adams, and A. Sen, Macromolecules, 27, 2694 (1994).

7. T. K. Wu, D. W. Ovenall, and H. H. Hoehn, in "Applications of Polymer Spectroscopy”, E. G. Brauer, Ed., Academic Press, Inc., New York, N.Y., 1978, p 19.

8. R. J. Angelici, Acc. Chem. Res., 5, 335 (1992).

9. S. Otsuka and A. Nakamura, , J. Am. Chem. Soc., 95, 3180 (1972).

10. F. Rivetti and U. Romano, J. Organomet. Chem., 154, 323 (1978).

11. J. S. Brumbaugh, R. R. Whittle, M. Pavez, and A. Sen, Organometallics, $\mathbf{9}, 1735$ (1990).

12. H. K. Luo and D. G. Li, Acta Polym. Sin., 3, 299 (1998).

13. A. Vavasori and L. Toniolo, J. Mol. Catal. A: Chem., 110, 13 (1996).

14. A. S. Abu-Surrah, G. Eckert, W. Pechhold, W. Wilke, and B. Rieger, Macromol. Rapid. Commun., 17, 559 (1996).

15. A. S. Abu-Surrah, R. Wursche, B. Rieger, G. Eckert, and W. Pechhold, Macromolecules, 29, 4806 (1996).

16. P. Aaltonen and B. Lofgren, Macromolecules, 28, 5353 (1995).

17. J. M. Lagaron, M. E. Vickers, A. K. Powell, and N. S. Davidson, Polymer, 41, 3011 (2000).

18. B. J. Lommerts, E. A. Klop, and J. Aerts, J. Polym. Sci., Part B: Polym. Phys., 31, 1319 (1993). 